DOI https://doi.org/10.18551/rjoas.2021-02.13

\title{
SMALL-SCALE FOOD CROPS PRODUCTION AS A VERITABLE TOOLS FOR POVERTY ALLEVIATION IN SOUTH-SOUTH RURAL HOUSEHOLDS, NIGERIA
}

\author{
Emaziye P.O.*, Inoni E.O. \\ Department of Agricultural Economics and Extension, Faculty of Agriculture, \\ Delta State University, Asaba, Delta State, Nigeria \\ ${ }^{\star}$ E-mail: peteremaziye63@gmail.com
}

\begin{abstract}
The main objective of the study was to analyze the mean percentage contributions of food crops farmers' sources of annual incomes. 384 respondents were obtained using multi-stage sampling procedures and data were collected with the aid of structured questionnaires. Data were analyzed using descriptive statistics. The study area was dominated by male gender households head having family size of 11 persons. Most respondents were well experienced in farming with secondary educational level and with aged farmers. The mean annual incomes of $\$ 39,066.67$ (\$102.48) revealed that respondents were poor. Food crops production contributed $31.0 \%$ income to the total annual incomes which was quite substantial. Most food crops grown were cassava, maize and yam. Major constraints of respondents were lack of money and flooding. The study recommends that greater focus should be given to food crops production as it can be used as veritable tools for poverty alleviation.
\end{abstract}

\section{KEY WORDS}

Alleviation, crops, small-scale, tools, poverty, rural households.

Poverty was defined by Aderonmu (2010) as the deficient of command over necessary consumption needs. Agwu and Kadiri (2014) defined "poverty as a state when the resources of families or individual persons are not sufficient to give an acceptable social standard of living". Uma and Eboh (2013) asserted that poverty in developing countries such as Africa countries is chronic, massive and pervasive, affecting greater portions of the African societies.

Awotide et al, (2015) reported that most farmers cultivated food crops such as maize, cowpea, cassava and yam in Nigeria. Emaziye (2020) stated that cassava, yam and maize were the most common food crops grown in Delta State, Nigeria. Onyenwoke and Simonyan (2014) stated that one of the important food crop grown in Nigeria and globally is cassava. Also Ferraro et al., (2015) reported that Yam (Dioscorea spp.) and Cassava (Manihot esculenta) were tropical crops consumed by about two billion people which represent main source of carbohydrate and energy for about 700 million persons in the sub-tropical regions. Surajo et al., (2018) reported that the serious phenomenon in Nigeria is poverty that affects Nigerian population leaving the country as one of the poorest country globally.

World Bank (2015) stated that poverty status is measured using economic dimension based on consumption and income. Yalogama and Chilesha (2016) stated that "Poverty reduction programmes globally were aimed at alleviating poverty of the vulnerable communities and the poor through community-demand-driven and participatory strategies. Singh and Chudasama (2020 reported that poverty reduction strategies need to be adopted simultaneously for a comprehensive poverty reduction driven.

Hussaini (2014) reported that "since Nigeria Independence the struggle against poverty has been a central focus of development planning but development programmes aim to reduce poverty were either abandoned or neglected completely by successive government in Nigeria". Nkwede (2014) stated that "issues of poverty have been a lot of concern to both private individuals and successive administrations in Nigeria but various efforts to reduce poverty has not yielded the required results". 
Taiwo and Agwu (2016) stated that poverty reduction programmes by NGOs and government were not successful in addressing poverty reduction but rather a means of looting the public coffers. Singh and Chudasama (2020) stated that some degrees of strategies were needed to compliment the series of approaches to poverty reduction that needs urgent implementations. United Nations Development Programme (2014) affirmed that capabilities' approach is needed for measurement of poverty.

Food crops production would bridge the gap between poverty and rural households in South-South, Nigeria.

Objectives of the study:

- Examine the socio-economic characteristics of food crops farmers;

- Examine the food crops farmers annual income;

- Evaluate food crops farmers sources of income;

- Determine food crops farmers enterprises;

- Analyze mean percentage contribution of sources of annual incomes;

- Examine the constraints of food crops farmers.

\section{METHODS OF RESEARCH}

The South-south geopolitical zones of the country Nigeria is made up of Six states namely rivers, Edo, Delta, Cross River, Bayelsa and Akwa-lbom. The zone has a diverse ethnic nationalities and hub of Nigerian economy with the presence of crude oil in the area. The South-South, Nigeria has about $85,303 \mathrm{~km}^{2}$ land mass and a population of about $21,014,655$ persons (NPC, 2006). The occupation of the zone is agriculture.

Multi-stage sampling technique was used in random adoption of 384 food crops farmers. Firstly, were the random selections of three states from the six states that make up the South-south of Nigeria. Secondly was the random adoption of four Local Government Areas giving a total of 12 local Government areas. Thirdly were the random adoption of four rural farming communities each giving a total of 48 rural farming communities and lastly were the random selection of eight food crops farmers giving a total of 384 food crops farmers utilized for the research study.

Data for the study were obtained with the aid of well-structured questionnaires administered to respondents. The data obtained were analysed using descriptive statistics such as percentages, frequencies, mean and mode.

\section{RESULTS AND DISCUSSION}

The socio-economic characteristics of food crops farmers. The study revealed that male gender household head with a mean age of 49 years dominated the area. Most respondents were married with large family size of 11 persons that mostly have secondary school educational level. Most respondents were well experienced in crop production with a mean farming experience of 20 years as shown in Table 1. These research findings agreed with Emaziye (2020) who stated that most crop farmers were married, aged and with low level of education in Niger Delta Region, Nigeria.

Table 1 - The socio-economic characteristics of food crops farmers

\begin{tabular}{lccc}
\hline & $\begin{array}{c}\text { Frequency } \\
(\mathrm{n}=384)\end{array}$ & Percentage (\%) & Mode/Mean \\
\hline Age (years) & 41 & 10.7 & 49 years \\
$27-38$ & 169 & 44.0 & \\
$39-50$ & 147 & 38.3 & Male \\
$51-62$ & 27 & 7.0 & \\
$63-74$ & & 41.9 & 58.1 \\
Gender (Household heads) & 161 & & \\
Female & 223 & & \\
Male & & & \\
Family Size (persons) & &
\end{tabular}




\begin{tabular}{lccc}
\hline Table 1 Continue & & & \\
$4-7$ & 42 & 10.9 & 11 persons \\
$8-11$ & 149 & 38.8 & \\
$12-15$ & 162 & 42.2 & Married \\
$16-19$ & 31 & 8.1 & \\
Marital Status & & 53.6 & \\
Married & 206 & 27.1 & \\
Widow & 104 & 7.8 & \\
Single & 30 & 11.5 & \\
Divorced & 44 & 22.7 & \\
Education Status & & 33.3 & \\
No formal education & 87 & 37.2 & 20 years \\
Primary school & 128 & 6.8 & \\
Secondary school & 143 & & \\
Tertiary school & 26 & 24.7 & \\
Farming Experience (years) & & 35.7 & \\
$1-12$ & 95 & 39.6 & \\
$13-24$ & 137 & & \\
$25-36$ & 152 & & \\
\hline
\end{tabular}

Source: Field data.

Mean Annual incomes of food crops farmers. The mean annual incomes from crop production was $\$ 12,100$, small-scale livestock production was $\$ 10,067$, fisheries production was $\$ 7,333$ and petty trading was $\$ 9,567$. The mean annual income of food crops farmers was $\$ 39,066.67$ (\$102.48) which resulted to $\$ 107.03$ (\$0.28) per day as shown in Table 2. These incomes revealed that South-South rural crop farmers were poor with low income per capita. This work is in line with the findings of Olawepo (2010) that majority of rural farmers were poor with low annual incomes in Nigeria.

Table 2 - Mean Annual incomes of food crops farmers

\begin{tabular}{|c|c|c|c|c|c|}
\hline Income & $\begin{array}{l}\text { Delta } \\
(A)\end{array}$ & $\begin{array}{l}\text { Edo } \\
(\AA)\end{array}$ & $\begin{array}{c}\text { Rivers } \\
(\AA)\end{array}$ & $\begin{array}{c}\text { Entire Area } \\
(\mathbb{A})\end{array}$ & $\begin{array}{l}\text { Mean } \\
(A)\end{array}$ \\
\hline Crops & 12,000 & 12,500 & 11,800 & 36,300 & 12,100 \\
\hline Small-scale livestock & 11,200 & 10,000 & 9,000 & 30,200 & 10,067 \\
\hline Fisheries & 6,500 & 4,900 & 10,600 & 22,000 & 7,333 \\
\hline Petty trading & 8,600 & 10,100 & 10,000 & 28,700 & 9,567 \\
\hline Total ( $($ ) & 38,300 & 37,500 & 41,400 & 117,200 & $39,066.67$ \\
\hline
\end{tabular}

Source: Field data.

Mean percentage contributions to sources of incomes. The parameters in Table 3 clearly shows the various percentage contributions to sources of annual incomes. Crop production contributed $31.0 \%$, small-scale livestock production contributed $25.8 \%$, fisheries production contributed $18.8 \%$ and petty trading contributed $24.4 \%$. From the contribution of incomes to annual income, crop production contributed most $(31.0 \%)$ which was quite substantial. Crop production could be used for poverty reduction if more attention is given to its production the south-south rural households. These collaborated with the study of Berresaw et al., (2011) that crops plays a pivoted role out of poverty in Uganda. Also this findings agreed with the findings of John and Dankawu (2014) that agricultural production could be used in reduction of poverty in Nigeria.

Table 3 - Mean percentage contributions to sources of incomes

\begin{tabular}{|c|c|c|}
\hline Sources of Income & Entire Area $(\mathbb{N})$ & Percentage (\%) \\
\hline Crops & 12,100 & 31.0 \\
\hline Small-scale livestock & 10,067 & 25.8 \\
\hline Fisheries & 7,300 & 18.8 \\
\hline Petty trading & 9,567 & 24.4 \\
\hline Total ( & $39,066.67$ & \\
\hline
\end{tabular}

Source: Field data computation. 
Food crops farmers' enterprises. The most crops cultivated in the south-south, Nigeria were cassava, yam and maize. But cassava production (40.0\%) dominated the study area followed by maize production $(33.0 \%)$ while yam farming $(27.0 \%)$ was the least been cultivated in the area as shown in Table 5. This is similar to the findings of Emaziye (2020) that rural farming cooperator and non-cooperators mostly cultivated maize, yam and cassava in Delta State, Nigeria.

Table 4 - Food crops farmers' enterprises

\begin{tabular}{lcccc}
\hline \multicolumn{1}{c}{ Enterprises } & Delta $(\mathrm{n}=128)$ & Edo $(\mathrm{n}=128)$ & Rivers $(\mathrm{n}=128)$ & Entire Area $(\mathrm{n}=384)$ \\
\hline Cassava & $124(40.5 \%)$ & $127(39.8 \%)$ & $110(39.6 \%)$ & $361(40.0 \%)$ \\
Yam & $82(26.8 \%)$ & $89(27.9 \%)$ & $73(26.3 \%)$ & $244(27.0 \%)$ \\
Maize & $100(32.7 \%)$ & $103(32.3 \%)$ & $95(34.1 \%)$ & $298(33.0 \%)$ \\
\hline
\end{tabular}

Source: Field data. Multiple responses observed.

Constraints of food crops farmers. The major constraints experienced by food crops farmers as shown in Table 5 were flooding $(23.0 \%)$, lack of money $(23.5 \%)$, excessive heat $(20.2 \%)$, irregular rainfall pattern (21.3\%) and sickness (12.0\%). The most constraints faced by food crops farmers were lack of money and flooding. In the absence of fund as a result of flooding that destroyed their farm investments, the rural food crops farmers would be faced with poverty and hunger. This study is in agreement with Olaolu and Akinnagbe (2014) that lack of credits facilities and poverty level of farmers among others were the major constraints facing agricultural production in Nigeria.

Table 5 - Constraints of food crops farmers

\begin{tabular}{lcccc}
\hline \multicolumn{1}{c}{ Constraints } & Delta $(\mathrm{n}=128)$ & Edo $(\mathrm{n}=128)$ & Rivers $(\mathrm{n}=128)$ & Entire Area $(\mathrm{n}=384)$ \\
\hline Flooding & $120(22.3 \%)$ & $103(19.7 \%)$ & $126(25.6 \%)$ & $358(23.0 \%)$ \\
Lack of money & $123(22.9 \%)$ & $124(23.7 \%)$ & $120(24.4 \%)$ & $367(23.5 \%)$ \\
Excessive heat & $120(22.4 \%)$ & $123(23.6 \%)$ & $72(14.7 \%)$ & $315(20.2 \%)$ \\
Irregular rainfall pattern & $110(20.5 \%)$ & $121(23.2 \%)$ & $101(20.5 \%)$ & $332(21.3 \%)$ \\
Sickness & $64(11.9 \%)$ & $51(9.8 \%)$ & $73(14.8 \%)$ & $188(12.0 \%)$ \\
\hline
\end{tabular}

Source: Field data. Multiple responses observed.

\section{CONCLUSION AND RECOMMENDATIONS}

The study showed that the area is dominated by male gender households head having family size of 11 persons. Most respondents were well experienced in farming with secondary education level and with aged farmers. The mean annual income of $\$ 39,066.67$ (\$102.48) revealing farmers poverty level. The percentage contribution of incomes of respondents was substantial indicating that food crops production could be used as a tool for poverty reduction if more attention is given to its production. Most food crops grown in the area were cassava, maize and yam and the respondents experienced major constraints in the area of lack of funds and flooding that destroyed their farm investments thereby resulted to poverty of food crops farmers. The study recommends that greater attention should be given to food crops farming as it can act as a veritable tools for poverty alleviation.

\section{REFERENCES}

1. Aderonmu, J.A. (2010). "Local Government and Poverty Eradication in Rural Nigeria. Canadian Social Science. 6(5): 200-208.

2. Agwu, M.E and K.I. Kadiri (2014). "Analysis of critical strategic factors for successful implementation of poverty alleviation programmes in Nigeria. International Journal of Computational Engineering and Management, 17(1): 1-9.

3. Berresaw, M.K., B. Shiferaw and G. Muricho (2011). "Agricultural Technology, crop income, and poverty alleviation in Uganda. World Development 39(10): 1784-1795 
4. Emaziye, P.O (2020). "Constraints and socio-economic analysis of food crops production in Delta State, Nigeria. International Journal of Applied Research and Technology 9(11): 9-14.

5. Emaziye, P.O (2020). "Economic Analysis of co-operatives societies and agricultural productivity in Rural Households in Delta State, Nigeria". International Journal of Agricultural Science, Research and Technology in Extension and Education Systems (IJASRT in EESs) 10 (4): 145-148.

6. Hussaini, M. (2014). "Poverty Alleviation Programmes in Nigeria: Issues and Challenges. International Journal of Development Research vol 4(3): 717-720.

7. John M.A and M.U Dankawu (2014). "Effect of Agriculture on Poverty reduction in Nigeria: A multifaceted Approach using Principal component analysis. IOSR Journal of Humanities and Social Sciences Volume 23, issue 6, pp 35-43.

8. Nkwede, J.O (2014). "Approaches for Poverty Alleviation and Sustainable Development in Nigeria: A study of Ebonyi State Community based Poverty Reduction Agency (EBCPRA). International Journal of Social Sciences Studies Vol 2(1): 153-163.

9. Olaolu, M.O and Akinnagbe, O.M (2014). "Constraints and strategies for improving agricultural intervention programmes in Nigeria: A case of National Fadama development Project Phase II in Kogi State, Nigeria. Journal of Agricultural Extension vol 18 (2): 164176.

10. Olawepo, R.A (2010). "Determining rural farmers' income: A rural Nigeria experience. Journal of African Studies and Development vol 2(4): 99-108.

11. Singh, P.K and Chudasama, H (2020). "Evaluating poverty alleviation strategies in a developing countries. PLOS ONE 15(1).

12. Taiwo, J.N and M.E Agwu (2016). "Problems and Prospects of Poverty Alleviation Programmes in Nigeria. International Journal of Business and Management Review vol. 4, No. 6, pp. 18-30.

13. Uma, K.E and F.E. Eboh (2013). "Corruption Perception Index. http://www.transparency.org/cpi2014/results

14. United Nations Development Programmes (2014). "Eradicate extreme poverty and hunger: where do we stand?. The United Nations Development Programme (UNDP), New York, USA.

15. Awotide, D.O., Ikudaisi O.J, Ajala S.O and Kaltungo J.H (2015).

16. Emaziye, P.O (2020). "Constraints and socio-economic analysis of food crops production in Delta State, Nigeria. International Journal of Applied Research and Technology Vol 9(11):9-14.

17. Feraro V.C., Piccirillo, K., Tomlins and M.E. Pintabo (2015). "Cassava (Manihot esculenta crantz) and Yam (Discorea spp) crops and their derived foodstuff: safety security and nutritional value. Critical Reviews in Food Science and Nutrition 56(16): 2714-2729

18. Onyenwoke C.A and K.J Simonyan (2014). "Cassava Post-harvest processing and storage in Nigeria: A Review. African Journal of Agricultural Research vol 9(53): 38533863.

19. Singh, P.K and H. Chudasama (2020). "Evaluating poverty alleviation strategies in a developing country. PLOS ONE 15 (1): 1-10.

20. Surajo, A.Z, Umir, A.S, J. Musa and M.J., Haruna (2018). "Poverty Alleviation and Sustainable Development in Nigeria: A critical Review. Journal of Rural Technology and Entrepreneurship Development (JORTED) vol 1 (1): 1-10.

21. World Bank (2015). "The World Bank Report 2015. The World Bank, Washington D.C USA.

22. Yalogama, S. and N.M. Chileshe (2016). "Critical success factors for community driven development projects: A Sri Lankan Community perspective. International Journal of Project Management vol 34: 643-659. 